\title{
Isabel Extravís Hernández, Jerónimo Zurita (1512-1580). Humanismo e Historia al servicio del Reino y la Corona. Madrid: Centro de Estudios Políticos y Constitucionales, Madrid, 2018, 367 págs.
}

En un libro anterior -Jerónimo Zurita (1512-1580). Un esbozo biográfico, 2014 - la autora presentó al público un avance de este que ahora comentamos, sin duda mucho más ambicioso y más fundamentado en fuentes y bibliografía. En ambos se nos da una imagen completa de la persona y de su obra, pasando por el proceso a través del que Zurita devino cronista, en paralelo a su cursus honorum en la administración de la monarquía de Felipe II.

Puede decirse que es un libro a medio camino entre la microhistoria y la biografía de personajes notables. Quizá por esto se otorga una gran importancia al contexto vital de Jerónimo Zurita, de modo que Zaragoza, Valladolid, Alcalá de Henares y todos aquellos espacios donde residió o por los que pasó están apropiadamente descritos en su trama urbana y su contexto social. La familia del erudito, de dónde, quién y qué influencias recibió en su existencia personal es casi tan importante como el acercamiento a las bibliotecas, y a los libros, tanto impresos como manuscritos, que ocupan parte importante de su correspondencia con otros eruditos, en especial Páez de Castro, con quien compartía interés por la Historia. De hecho, las cartas son una pieza importante en este libro, no en vano permiten un acercamiento a la persona de Zurita desde un plano no exactamente íntimo, pero sí cercano: recordemos que el género epistolar era en el siglo XVI el hilo que unía a intelectuales que compartían intereses comunes, si bien es cierto que la conservación de las cartas suele ser síntoma de una elevada idea de quien escribe y el afán de perpetuarse a través de ellas. Igual o más importante es el interés y el acercamiento de Zurita a los archivos, lo que responde a su condición de servidor del rey y de la Inquisición y al manejo de papeles, circunstancias todas ellas que le facilitaron ocasiones para consultar importantes y voluminosos fondos documentales. En este sentido es de interés señalar que Fernando de Valdés, arzobispo de Sevilla e Inquisidor General, le encomendó que reuniese e inventariase todas las bulas, breves y documentos para que se custodiasen en el Tribunal del Santo Oficio de Aragón. A mayor abundamiento, Zurita fue nombrado cronista de Aragón en 1548 y con ese motivo obtuvo permiso para entrar en todos aquellos archivos que necesitase, cosa que de hecho hizo en muchos de ellos.

Zurita se sitúa en un período historiográfico fundamental. El desarrollo de la historiografía humanista italiana y su éxito en la Europa Occidental dio lugar a una fuerte efervescencia de estudios del pasado propiciada por la edición de las crónicas medievales que permanecían manuscritas; por el interés de los poderes civiles en su glorificación basada en el pasado, ya fuese el rey, ya los territorios bajo su gobierno o las ciudades —más bien las oligarquías que las dominaban-; por el afán, no menos intenso, del alto clero en fortalecer su imagen utilizando el pasado en su propio beneficio; o por la proliferación de genealogías que, desde un interés privado, convertían la Historia en compañera de la sangre en la reivindicación de linajes cuyo origen era más que dudoso en muchos casos. Faltos de formación específica - la Historia no formaba parte del curriculum académico en ninguno de sus niveles-, los cronistas eran deudores de sus lecturas y en casos como el de Zurita, de su formación jurídica y de su experiencia en el tratamiento de documentos, lo que le aportaba un método de crítica por comparación. La falta de formación y de orientación se tradujo en 
otros cronistas —el caso más claro sería el del siempre vilipendiado Florián de Ocampo - en la admisión de todo tipo de fantasías o en la creación de algunas, pero no así en Zurita, cuya forma de trabajar, apegada al documento, lo colocó a salvo de esas vanidades que buscaban fama y no eficacia argumental. Si la Corona de Aragón encontró en Zurita a un erudito comprometido, que culminaría con la redacción de sus Anales, Castilla disfrutó en la segunda mitad del XVI de una generación de cronistas que se caracterizaron por su esfuerzo en la documentación a través de los archivos, su interés en fundamentarse en la autenticidad de los documentos y su buen estilo al escribir. Al respecto, Zurita fue superior al menos en los dos primeros aspectos. Muertos Zurita, Ambrosio de Morales y Arias Montano, entre pocos más, quedaba Juan de Mariana como historiador reconocido, pero con ellos murió esa fase de crónica de calidad y se abriría en los últimos años de Felipe II otra fase contaminada de falsificaciones al servicio de los intereses antes mencionados, coincidiendo con la crisis de las demás áreas de labor intelectual que duraría hasta el último tramo del siglo XVII.

El desarrollo del libro sigue grosso modo una línea cronológica, aunque dividida de una manera original en cuatro grandes capítulos a partir del formato de las diferentes firmas que el cronista utilizó en vida (p. 3) - Gerónimo Çurita de Alfaro (1512-1536), Hieronimus Suritae (1536-1548), Gero. ${ }^{\text {MO }}$ Çurita (1548-1566) - y una cuarta con la manera habitual con la que en la actualidad nos referimos a dicho autor, Jerónimo Zurita (1566-1580). Tras un breve prólogo firmado por Ricardo García Cárcel y una sugerente presentación de la obra a modo de introducción, hecha esta por la propia autora, el primero de los apartados se fundamenta en el estudio de los orígenes familiares, especialmente de la rama de los Zurita. Estos no son del todo claros, pues la información genealógica que se conoce con seguridad se limita exclusivamente a la existencia de su abuelo paterno, Gabriel, del que solamente se señala el matrimonio del que nacería el padre del cronista, el médico Miguel Zurita, sin que haya más información relativa ni a otros descendientes ni a otros antepasados. En un ejercicio crítico sobre este hecho, aunque ciertamente con más preguntas que respuestas, la autora presenta la sospecha razonable de que el desconocimiento de los ascendentes no se deba a una laguna documental accidental, sino que se debería a una acción deliberada por parte de Jerónimo Zurita, la cual respondería a la voluntad del cronista de esconder sus hipotéticas raíces mudéjares o judías, siendo la primera de las dos posibilidades la más probable, aunque en todo caso en un escenario que no ha sido posible verificar.

Independientemente de sus raíces, son interesantes ciertas paradojas entre su vida pública y privada con respecto a la familia y a las estrategias hereditarias, ya que si en su faceta pública criticaba la cesión de oficios y beneficios por esta vía, con la llegada a la mayoría de edad, su padre, Miguel Zurita, le traspasó aquellos cargos relacionados "con los Merindados de Huesca, Barbastro y Almudévar y las Baylias de Huesca y Aldeahuesca y el oficio de juez de apelación de moros" (p. 58). A estos se le añadirían en 1530 el de contino de la casa de Carlos V, el cual mantuvo toda su vida, aunque tras 1556 el servicio se dirigió lógicamente al nuevo rey, Felipe II. A su vez, el propio Jerónimo intentará al final de su vida traspasar varios de los oficios que regentaba en la persona de su último hijo, también Jerónimo, cosa que consigue con los de baile y merino de Huesca y Aldeahuesca, manteniendo la transmisión que, como poco, había comenzado el abuelo Miguel. De esta manera, su experiencia como genealogista no solamente le sirvió en su carrera profesional, sino que a través de este conocimiento consiguió una continuidad de los cargos citados en su familia durante tres generaciones, hasta la muerte de su hijo Jerónimo en 1600. 
Más allá de las herencias materiales, lo que sí es cierto es que nuestro protagonista se crio en un ambiente propicio para crear y desarrollar sus posteriores habilidades humanísticas. Hijo del reconocido médico Miguel Zurita, de cuyos conocimientos se sirvieron los reyes Fernando el Católico y Carlos V - e incluso Francisco I de Francia a finales de 1525 en su obligada residencia en el alcázar de Madrid tras la batalla de Pavía-, "el ambiente cultural en el que nació Zurita debió ser determinante en su formación” (pp. 41-42). Al igual que su padre, fue ordenado de corona (1558) y también estudiante universitario, si bien Jerónimo realizó sus estudios en la Universidad castellana de Alcalá y no en la de Huesca, como aquel, y aunque no existe la completa certeza, estos debieron ser los de Artes. Además de servir de habilitación para ejercer los oficios con los que fue honrado en una monarquía que se estaba construyendo inexorablemente sobre papeles, su paso por Alcalá le proporcionó contacto con compañeros con los que mantuvo amistad toda su vida —Páez de Castro, Cazalla y Marquina y Francisco de Bobadilla y Mendoza- y con destacados intelectuales, profesores de la Universidad de Alcalá, como Lorenzo Balbo de Lillo, Juan de Vergara, León de Castro o el mismo Francisco de Vitoria.

El segundo de los bloques, Hieronimus Suritae (1536-1548) se centra en dos grandes aspectos del humanista aragonés. Por una parte, en relación a su desempeño como secretario de la Inquisición, cargo que heredará de su suegro Juan García, del que primero sirve como asistente (1536) y más tarde como titular de pleno derecho. De su familia política - a través del matrimonio con Juana García de Oliván—, no solo sacará provecho de las redes tejidas por su suegro, sino que un año más tarde de incorporarse como secretario del Santo Oficio será nombrado notario eclesiástico por Jerónimo Pérez García, pocos meses antes de convertirse en su cuñado. Por otra parte, en relación a su biblioteca, en la cual invertía buena parte de las rentas que obtenía como titular de los oficios anteriormente citados y de la que no se conserva ningún inventario en los sucesivos lugares en los que estuvo. Dicho esto, sí existe información sobre la misma en la Real Academia de la Historia, casi siempre en formato de listas de libros, de las cuales se ha podido obtener qué autores y títulos formaron parte de ella, así como las materias en las que se encuadraban aquellos. En cuanto a la temática, la Historia es la más abundante, algo excepcional si tenemos en cuenta que la presencia de esta disciplina en las bibliotecas del momento en general no superaba el 5\% de los volúmenes, orientados en su mayoría a la religión y al derecho, aunque la excepcionalidad estaría por supuesto en relación con su oficio de cronista. En sus fondos destacan, entre otras, crónicas medievales y modernas en latín, así como obras de oradores y poetas clásicos. Y, por supuesto, las obras de temática religiosa, en forma de biblias y libros de liturgia antigua.

El tercer bloque, Gero. ${ }^{\text {mo }}$ Çurita (1548-1566) aborda quizás el período más interesante y desde luego más conocido de su biografía, aquel en el que sirvió como Cronista del Reino de Aragón (1548), un año después de que las Cortes aragonesas reunidas en Monzón aprobasen la creación y provisión de dicho cargo. También en 1548 ocurrieron otros dos hechos relevantes, uno en su vida personal, como lo fue la muerte de su esposa, Juana García de Oliván, seguramente como consecuencia del parto de su quinto y último hijo, Jerónimo, a la postre el heredero del cronista; y otro en su vida profesional, pues también en ese momento fue substituido como secretario de la Inquisición, en una maniobra en la que a través de su promoción como contador general de la Inquisición en la Corona de Aragón, el nuevo inquisidor Fernando Valdés se 
aseguraba el desplazamiento de los cargos nombrados por el anterior inquisidor, Tavera, para que estas vacantes fuesen ocupadas por miembros de su grupo de confianza.

Tras su nombramiento como Secretario del Consejo y de la Cámara de Felipe II en 1566, la autora combina con audacia los problemas que la multiplicidad de cargos y sobre todo de lealtades institucionales pudieron suponer y de hecho supusieron a la persona de Zurita. Trabajar a lo largo de su vida al servicio del Tribunal del Santo Oficio como secretario y contador, al servicio de la Monarquía como "contino" de Carlos V y de Felipe II, y como secretario del Consejo y de la Cámara de este último, y a su vez al servicio de los intereses de la Corona de Aragón como cronista de dicho territorio no siempre fue fácil, porque la Monarquía se sirvió en este momento de la Inquisición para combatir delitos de carácter civil y, con ello, conseguía de alguna manera interferir en la autonomía de la institución, algo que afectaba directamente al protagonista de la obra. Por debajo de los casos particulares, el fundamento de muchas controversias entre las distintas instituciones o facciones giraban en torno a la cuestión del foralismo aragonés, en un momento además muy relevante por tratarse de los años inmediatamente anteriores al proceso contra Antonio Pérez y en los que tomaron forma las conocidas como Alteraciones de Aragón.

En cierta medida, buena parte de las críticas que recibió tras la publicación Los Anales de la Corona de Aragón, su obra capital, se debieron a esta doble vinculación institucional. Por una parte, desde Castilla se le reprochó la calidad del castellano utilizado, en su estilo y ortografía, además de reprenderle por la incorporación de voces y expresiones aragonesas que ningún significado tenían en la lengua elegida para la edición de la obra. De la parte aragonesa, las críticas se vertieron mayoritariamente por familias particulares que, presumiéndose con relevancia suficiente para aparecer en un libro como aquel sobre la Historia del Reino de Aragón, no lo estaban, o bien por su irrelevancia, o bien por sus más que dudosos méritos y orígenes; pero también fue criticado por aquellos que no veían en los Anales una reivindicación suficiente de la autonomía y singularidad del territorio aragonés en el entramado de la Monarquía.

En Jerónimo Zurita (1566-1580), el último de los capítulos del libro, la autora desglosa la actividad conocida del protagonista en los últimos años de su vida, en especial aquella que guarda relación con su oficio como Secretario de Felipe II, que es la fecha utilizada para arrancar este último bloque, y también el pensamiento político y el estilo de los Anales, su magna obra, la cual se sirve en lo posible del modelo de los Anales de Tácito. El nombramiento en lo más alto de la administración de la Monarquía Hispánica supuso el mayor reconocimiento a su carrera, aunque no fue el único que recibió hacia el final de su vida, pues también en estos años fue nombrado maestre racional de la ciudad de Zaragoza, donde residía varios meses al año obligado por su condición de cronista de Aragón.

Por los años que le tocó vivir, así como por la acumulación de oficios relevantes de distintas y a veces enfrentadas instituciones, y desde luego por su destacado papel como humanista, Jerónimo Zurita es un personaje de un interés capital para comprender con mayor profundidad la Historia de la Monarquía Hispánica del siglo XVI, y que desde luego merecía un trabajo como el que ha realizado Isabel Extravís Hernández. Además de un profundo análisis documental y una buena lógica en el desarrollo de hipótesis y argumentos, entre las virtudes de esta obra se encuentran también una exquisita corrección formal y una ordenada y atractiva exposición, todo lo cual redunda 
en una amena lectura. El hecho de contener imágenes, fragmentos textuales y árboles genealógicos - muy útiles en el primer y segundo capítulo del libro- no es en absoluto un adorno para la galería, sino que están perfectamente justificados y son de gran utilidad para el público no especialista. En definitiva, el contenido, la forma y sobre todo la perspectiva analítica de la obra son todas razones suficientes para agradecer y reconocer el trabajo realizado a la autora y para recomendar atentamente su consulta a los lectores de estas páginas.

Rubén Castro Redondo

Universidad de Cantabria (UC)

ruben.castro@unican.es

Fecha de recepción: 8 de octubre de 2019.

Fecha de aceptación: 2 de diciembre de 2019.

Publicación: 31 de diciembre de 2019

Para citar este artículo: Rubén Castro Redondo, “Isabel Extravís Hernández, Jerónimo Zurita (1512-1580). Humanismo e Historia al servicio del Reino y la Corona. Madrid: Centro de Estudios Políticos y Constitucionales, Madrid, 2018, 367 págs.", Historiografías, 18 (julio-diciembre, 2019): pp. 136-140. 